OPEN ACCESS

Edited by:

Anna Maria Testi,

Sapienza University of Rome, Italy

Reviewed by:

Qingbin Cui,

University of Toledo, United States

*Correspondence:

Chun-fung Sin

scf185@pathology.hku.hk

Specialty section:

This article was submitted to

Hematologic Malignancies,

a section of the journal

Frontiers in Oncology

Received: 27 October 2021 Accepted: 03 December 2021 Published: 23 December 2021

Citation:

Sin C-f and Man P-hM (2021) The Role of Proteasome Inhibitors in Treating Acute Lymphoblastic Leukaemia. Front. Oncol. 11:802832. doi: 10.3389/fonc.2021.802832

\section{The Role of Proteasome Inhibitors in Treating Acute Lymphoblastic Leukaemia}

\author{
Chun-fung $\operatorname{Sin}^{*}$ and Pui-hei Marcus Man \\ Department of Pathology, University of Hong Kong, Hong Kong, Hong Kong SAR, China
}

Acute lymphoblastic leukaemia (ALL) is an aggressive haematolymphoid malignancy. The prognosis of ALL is excellent in paediatric population, however the outcome of relapse/ refractory disease is dismal. Adult ALL has less favourable prognosis and relapse/ refractory disease is not uncommonly encountered. Bortezomib is the first generation proteasome inhibitor licensed to treat plasma cell myeloma and mantle cell lymphoma with favourable side effect profile. Efficacy of bortezomib had been proven in other solid tumors. Clinical studies showed promising response for proteasome inhibitors in treating relapse/refractory ALL. Thus, proteasome inhibitors are attractive alternative agents for research in treating ALL. In the review article, we will introduce different proteasome inhibitors and their difference in pharmacological properties. Moreover, the mechanism of action of proteasome inhibitors on ALL will be highlighted. Finally, results of various clinical studies on proteasome inhibitors in both paediatric and adult ALL will be discussed. This review article provides the insights on the use of proteasome inhibitors in treating ALL with a summary of mechanism of action in ALL which facilitates future research on its use to improve the outcome of ALL.

Keywords: proteasome inhibitors, acute lymphoblastic leukaemia, bortezomib, carfilzomib, ixazomib

\section{INTRODUCTION}

Acute lymphoblastic leukaemia (ALL) is an aggressive haematological malignancy. The prognosis of paediatric ALL is excellent with 90\% of long-term survivor (1). However, a small proportion of them still die from relapse/refractory disease. The prognosis of the adult population is poor, with only 50 $60 \%$ of long-term survivor (2). The prognosis of relapse/refractory disease is dismal.

Bortezomib is approved by Food and Drug Administration (FDA) for treatment of plasma cell myeloma and mantle cell lymphoma with reasonable side effect profile (3). Since then, bortezomib is an attractive novel agent for research in the treatment of other cancers, e.g., glioblastoma multiforme and colorectal cancer $(4,5)$. Bortezomib is also being researched for novel treatment of ALL with significant major discoveries made. Newer proteasome inhibitors are developed with improved efficacy and side effect profile. In this review article, it summarized the differences among 
various proteasome inhibitors and their mechanisms of action in ALL. Recent clinical studies to evaluate the role of proteasome inhibitors in ALL were highlighted. Finally, the future prospect of research about those agents in treating ALL will be proposed.

\section{DIFFERENCES IN PHARMACOLOGICAL PROPERTIES OF VARIOUS PROTEASOME INHIBITORS}

\section{Bortezomib}

Bortezomib is a first generation 26S proteasome reversible inhibitor which binds to $\beta 5$ subunit of chymotryptic site of $20 \mathrm{~S}$ subunit proteasome (6). It also binds to $\beta 1$ and $\beta 2$ subunits at lower affinity. Bortezomib can either be administered via intravenous or subcutaneous route with comparable amount of systemic concentration of drug and inhibitory action of proteasome. Bortezomib has haematological toxicities including thrombocytopenia and neutropenia which are not dose-limiting (7). Other common side effects are gastrointestinal side effects including diarrhoea, nausea, and vomiting which occur in $84 \%$ of patients. The most disabling adverse effect is peripheral neuropathy which is dose limiting and route-dependent, whereas subcutaneous administration has reduced incidence of this adverse effect (6).

\section{Carfilzomib}

Carfilzomib is a second generation proteasome inhibitor which belongs to epoxyketone group. This drug has irreversible binding towards $\beta 5$ subunit with higher $\beta 5$ to $\beta 2$ selectivity compared with bortezomib. The binding of carfilzomib to both $\beta 5$ and $\beta 2$ subunit makes it effective in treating bortezomib-resistant plasma cell myeloma $(6,8)$. This drug can only be administrated via intravenous route (6).

Carfilzomib associates with less risk of peripheral neuropathy compared with bortezomib. However, carfilzomib has a higher incidence of serious cardiotoxicity (9). It could be due to reduced number of proteasome per unit of protein in cardiac muscle (6, 8). Moreover, the off-target effect of inhibiting autophagy due to activation of protein phosphatase $2 \mathrm{~A}$ also contributes to carfilzomib-induced cardiotoxicity (10).

\section{Ixazomib}

Ixazomib is a boronate-based third generation proteasome inhibitor licensed to treat plasma cell myeloma and it can be administrated via oral route. It is a prodrug which will be hydrolyzed to form active metabolite and the active metabolite is reversibly bind to $\beta 5$ subunit and to lesser extent to $\beta 1$ and $\beta 2$ subunits of proteasome. However, the time of dissociation from $\beta 5$ subunit is shorter for ixazomib when compared with bortezomib $(6,11)$. Because the metabolite is similar to that of bortezomib, the incidence of grade 3 or more haematological and gastrointestinal side effects is comparable with bortezomib (6). However, the risk of peripheral neuropathy is lower than that of bortezomib $(6,12,13)$.

\section{Newer Classes of Proteasome Inhibitors}

Some newer classes of proteasome inhibitors are developing, namely oprozomib, delanzomib and marizomib with more favorable side effects profile.

Delanzomib shows similar potency of proteasome inhibition with both $\beta 5$ and $\beta 1$ subunit binding, in contrast to bortezomib binds only $\beta 5$ subunit (14). Delanzomib shows higher affinity of binding with 20 times slower rate of dissociation compared with bortezomib (15). A phase I/II study of delanzomib showed that grade 3 or above hematological side effects were common: anemia (15\%), neutropenia (23\%) and thrombocytopenia (54\%) at a dose of $2.1 \mathrm{mg} / \mathrm{m}^{2}$. Other non-hematological side effects included rash, nausea and diarrhea. A small proportion of patients had grade 1 or 2 peripheral neuropathy (12\%). No patients had grade 3 or above peripheral neuropathy (16).

Oprozomib is an epoxyketone similar to that of carfilzomib and it shows irreversible binding of $\beta 5$ subunit. However, the affinity of bindings is higher than that of ixazomib (15). The most common grade 3 or above adverse events were nausea, vomiting, diarrhea and thrombocytopenia. Only rare occurrence of grade 2 or above peripheral neuropathy $(17,18)$.

Marizomib can bind $\beta 1, \beta 2$ and $\beta 5$ subunits of $20 \mathrm{~S}$ proteasome irreversibly with long duration $(6,19)$. Safety data from phase I clinical trials showed that hematological toxicities were milder than bortezomib and carfilzomib. The common non-hematological adverse events were nausea, diarrhea, fatigue. Occurrence of central nervous system toxicities including reversible hallucination and cognitive deterioration were seen. Cardiac events were much less common than bortezomib and carfilzomib. No patients had grade 3 or above peripheral neuropathy $(20,21)$.

\section{MECHANISM OF ACTION AND PRE- CLINICAL STUDIES IN ALL}

The mechanism of action of proteasome inhibitors on ALL are summarized in Figure 1.

\section{NF-kB Inhibition}

Study showed that bortezomib was able to stabilize I $\mathrm{KB}$ by preventing the degradation of $\mathrm{I} \kappa \mathrm{B}-\alpha$ and thus inhibit NF- $\kappa \mathrm{B}$ pathway in plasma cell myeloma (22). Inhibition of $\mathrm{NF}-\kappa \mathrm{B}$ pathway was found to be one of the mechanisms of therapeutic effect in ALL from a phase 1 clinical study in 2007 (23). Another earlier study in 2011 showed that bortezomib was active against relapse $\mathrm{T}$ lymphoblastic leukemia (T-ALL) by inhibiting the NF- $\kappa \mathrm{B}$ activity in primary leukemic cells of patients (24).

NOTCH 1 activating mutation accounts for $60 \%$ of T-ALL and it drives leukemogenesis by activating $\mathrm{NF}-\kappa \mathrm{B}$ pathway $(25,26)$. Therefore, it is reasonable to postulate that bortezomib is effective in NOTCH1-mutated T-ALL. Study showed that bortezomib enhanced degradation of transcription factor $\mathrm{Sp}-1$ and thus reduced NOTCH1 transcription (27). Pre-clinical study showed that bortezomib was more effective in T-ALL than in 


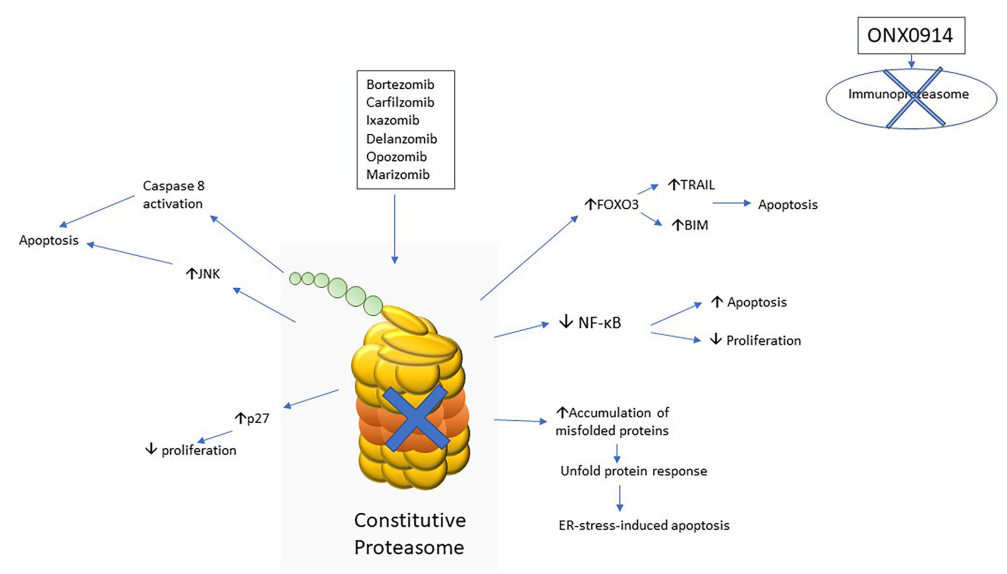

FIGURE 1 | Schematic diagram to show various mechanisms of action of proteasome inhibitors implicated in acute lymphoblastic leukaemia.

B lymphoblastic leukaemia (B-ALL) which probably due to the action of NF- $\kappa \mathrm{B}$ pathway inhibition by bortezomib (28). However, the NOTCH1 mutation status was unknown in that study.

It is uncertain that whether the treatment of proteasome inhibitors is also effective in NOTCH1 wild-type T-ALL, especially early $\mathrm{T}$-cell precursor acute lymphoblastic leukemia (ETP-ALL) which confers a poor prognosis. More studies are needed to address this issue.

\section{Targeting Immunoproteasome}

Immunoproteasome is a special type of proteasome that is expressed in hematopoietic cells. In contrast to the usual proteasome, or namely constitutive proteasome, immunoproteasome processes specific subunits $(\beta 1 \mathrm{i}, \beta 2 \mathrm{i}, \beta 5 \mathrm{i})$ in the active site. This results in an increased specificity to produce peptides with hydrophobic amino acid ends, which was hypothesized to facilitate antigen presentation (29).

In a recent study on proteasome subunit expression in leukemic cells from relapsed patients, it was found that immunoproteasome was more abundantly expressed in ALL than that in acute myeloid leukemia (AML). Thus, it accounted for increased sensitivity towards multiple proteasome inhibitors, including bortezomib, carfilzomib and ONX0914 (an irreversible $\beta 5$ i selective inhibitor) in ALL when compared with AML (30). Targeting immunoproteasome can achieve selective toxicities towards ALL and prevent those side effects resulting from constitutive proteasome inhibition of nonlymphoid tissue, e.g., cardiac toxicities. Pre-clinical study showed that B-ALL with KMT2A-AF4 fusion and T-ALL were highly sensitive to the treatment of ONX0914 (31).

\section{Restoration of Forkhead Box $\mathrm{O3}$ (FOXO3)}

Forkhead transcription factor family (FOXO) comprises different sub-classes namely forkhead box O1 (FOXO1), forkhead box O3a (FOXO3a) and forkhead box O4 (FOXO4). This transcription factor family, FOXO is responsible for regulating gene transcription related to apoptosis and cell cycle control. The activation of Akt phosphorylates FOXO3a and leads to translocation form nucleus to cytoplasm, preventing its transcription function. Philadelphia-positive acute lymphoblastic leukemia (Ph-positive ALL) is characterized by the presence of BCR-ABL1 fusion protein resulting from translocation of chromosome 9 and 22 and PI3K-Akt pathway is constitutively activated in this subtype of B-ALL (32). Jagani, Z. et al. showed a reduced level of FOXO3a expression in a BCRABL1 transgenic mice model in 2009. The treatment of bortezomib restored the level of FOXO3a by preventing proteasome-mediated degradation and prolonged survival in BCR-ABL1 transgenic mice. The level of FOXO3a target proteins, namely TRAIL and BIM were increased upon bortezomib treatment resulting into apoptosis (33). These findings were also verified in patients with Ph-positive ALL. A study in 2011 showed that treatment with bortezomib induced complete hematological response with disappearance of BCRABL1 transcript and restoration of FOXO3a (34).

Philadelphia-like acute lymphoblastic leukemia (Ph-like ALL) is a provisional entity in World Health Organization (WHO) 2016 classification with genetic signature significantly overlapping with $\mathrm{Ph}$-positive ALL and the prognosis is poor. Various kinases signaling pathway are hyperactivated, including PI3K-Akt pathway (35-37). It implies that FOXO3a will also be inactivated as a result and thus the treatment with proteasome inhibitors is potentially effective. However, no preclinical and clinical studies to verify this hypothesis.

\section{C-Jun Pathway}

C-Jun N-terminal kinase (JNK) has three isoforms (JNK1, JNK2 and JNK3) and it belongs to mitogen activated protein kinase (MAPK). JNK is activated by MAPK kinase and JNK phosphorylates c-Jun. Activation of c-Jun will in turn activate pro-apoptotic proteins, e.g., BAD and trigger subsequent apoptosis (38). Study showed that bortezomib activates c-Jun pathway resulting into apoptosis in plasma cell myeloma (39). 
The c-Jun activation by bortezomib was also demonstrated in BALL (40). However, no studies to evaluate the effect of proteasome inhibitors on c-Jun pathway in T-ALL so far.

\section{Modulation of Proteostasis}

Unfold protein response is triggered when there are stimuli to interfere protein folding in endoplasmic reticulum (ER) (41). If those misfolded proteins cannot be properly refolded again, they will be translocated out of ER and subjected to proteasomemediated degradation via $26 \mathrm{~S}$ subunit (42). Proteasome inhibition results into unfold protein response due to accumulation of misfolded proteins which triggered subsequent ER-stress-induced apoptosis (43). However, cells may restore proteostasis by upregulating molecular chaperones upon stimulation of unfold protein response triggered by ER stress. Therefore, maximal anti-leukemic effects can be achieved by inhibiting unfold protein response together with proteasome inhibition (44). A recent study utilized a casein kinase 2 (CK2) inhibitor, CX-4945 which inhibited the interaction between BIP (a sensor chaperone of ER stress) and Hsp90 (a molecular chaperone that stabilizes BIP). It resulted into impairment of BIP activities and thus inhibited the buffering function of unfold protein response against the ER stress induced by bortezomib pre-treatment. Similar effect was achieved by using a Hsp90 inhibitor, tanespimycin. The study also demonstrated synergistic effects of the above combination in various ALL cell lines (45).

When proteasome is inhibited, other pathways for protein haemostasis are activated to maintain cellular function which results into resistance to treatment with proteasome inhibitors. One such pathway is the activation of various molecular chaperones and deposition of misfolded protein aggregates in various deposition sites (46). Concurrent inhibition of molecular chaperones with the use of proteasome inhibitors will overcome the resistance and produce synergistic effect. Further studies on the modulation of proteostatic network by proteasome inhibitors and other chaperone inhibitors are needed in ALL.

\section{Other Mechanism}

Study showed that bortezomib was particularly active against KMT2A-rearranged ALL and increased the level of both KMT2A and $K M T 2 A$-fusion proteins. Bortezomib was able to trigger apoptosis via caspase 8 activation and lead to BID activation, with subsequent activation of $\mathrm{BAX}$ and $\mathrm{BAD}$. Moreover, bortezomib was able to induce $\mathrm{G} 2 / \mathrm{M}$ cell cycle arrest via induction of p27 transcription through promoting transcription activity of CDKN1B by accumulation of KMT2Afusion proteins upon bortezomib treatment (47). Similar therapeutic effect towards KMT2A-rearranged ALL was observed upon the treatment of carfilzomib. However, the underlying mechanism did not explore in that study (48).

\section{RESISTANCE MECHANISM TO PROTEASOME INHIBITORS}

Multiple mechanisms which lead to resistance to proteasome inhibitors in hematological malignancies have been described
(49). As $\beta 5$ subunit of the proteasome is the target of most proteasome inhibitors, point mutations in the binding pocket of proteasome inhibitors are one of the mechanisms (50-52). In addition, upregulation of the $\beta 5$ subunit by gene amplification leading to increased chymotrypsin activities and thus upregulation of NF- $\mathrm{KB}$ activities has also been suggested as a possible resistance mechanism in T-ALL cell lines (53).

Studies on reverting bortezomib resistance have been conducted. Interferon- $\gamma$ (IFN- $\gamma$ ) is known to induce immunoproteasome expression (29). Immunoproteasomes was found to be reduced in bortezomib-resistant T-ALL cell lines. In an in vitro study using TALL cell lines, IFN- $\gamma$ treated cells were able to demonstrate restored sensitivity towards proteasome inhibitors, including bortezomib, carfilzomib and ONX0914 (54). Therefore, combination of IFN- $\gamma$ and bortezomib could sensitize bortezomib-resistance leukemic cells towards bortezomib.

\section{CLINICAL STUDIES OF VARIOUS PROTEASOME INHIBITORS}

A phase 1 study in 2004 recruited 3 relapse/refractory ALL patients and treated with single agent bortezomib. The toxicities were tolerable. Those patients either showed blood count improvement or reduction in blast count, but no complete remission (CR) documented (55). Another phase 1 study in 2007 also demonstrated acceptable toxicities in pediatric patients with refractory ALL, though no clinical response observed (23) (Table 1).

Single treatment of bortezomib had limited efficacy. Therefore, various clinical studies utilizing combined treatment strategy had been conducted. Study by Messinger et al. in 2010 recruited 10 pediatric patients with relapse/refractory ALL and treated with combination of bortezomib, dexamethasone and chemotherapy. The response rate was $67 \%$ and majority of the adverse events were grade 3-4 hematological toxicities. Only 2 patients had grade 1-2 peripheral neuropathy (56). Recent study by Iguchi et al. recruited 6 pediatric patients with relapse/refractory B-ALL and treated them with bortezomib plus induction chemotherapy. The overall response rate was $80 \%$. However, $67 \%$ of them suffered from serious infective complications due to prolonged neutropenia. Five of them had grade 1-2 peripheral neuropathy and combination with vincristine could account for high rate of peripheral neuropathy (57). D. Hasegawa et al. recruited 3 Japanese pediatric relapse/refractory ALL patients and treated them with combined chemotherapy and bortezomib. All patients achieved CR and one patient achieved minimal residual disease (MRD) negativity after treatment. No fatal infective episodes occurred (58). Recent small-scale clinical studies also demonstrated excellent response to relapse/refractory ALL in pediatrics and young adults with CR rate around $60-80 \%$ and a substantial proportion of patients achieved MRD negativity. The side effects were acceptable (59-61).

Given the promising results of phase 1 studies, more largescale clinical studies were conducted. Study by Messinger et al. in 2012 recruited 22 patients with relapse/refractory ALL (1-22 years old). The overall response rate was $73 \%$ with few patients 
TABLE 1 | Data from clinical studies of proteasome inhibitors.

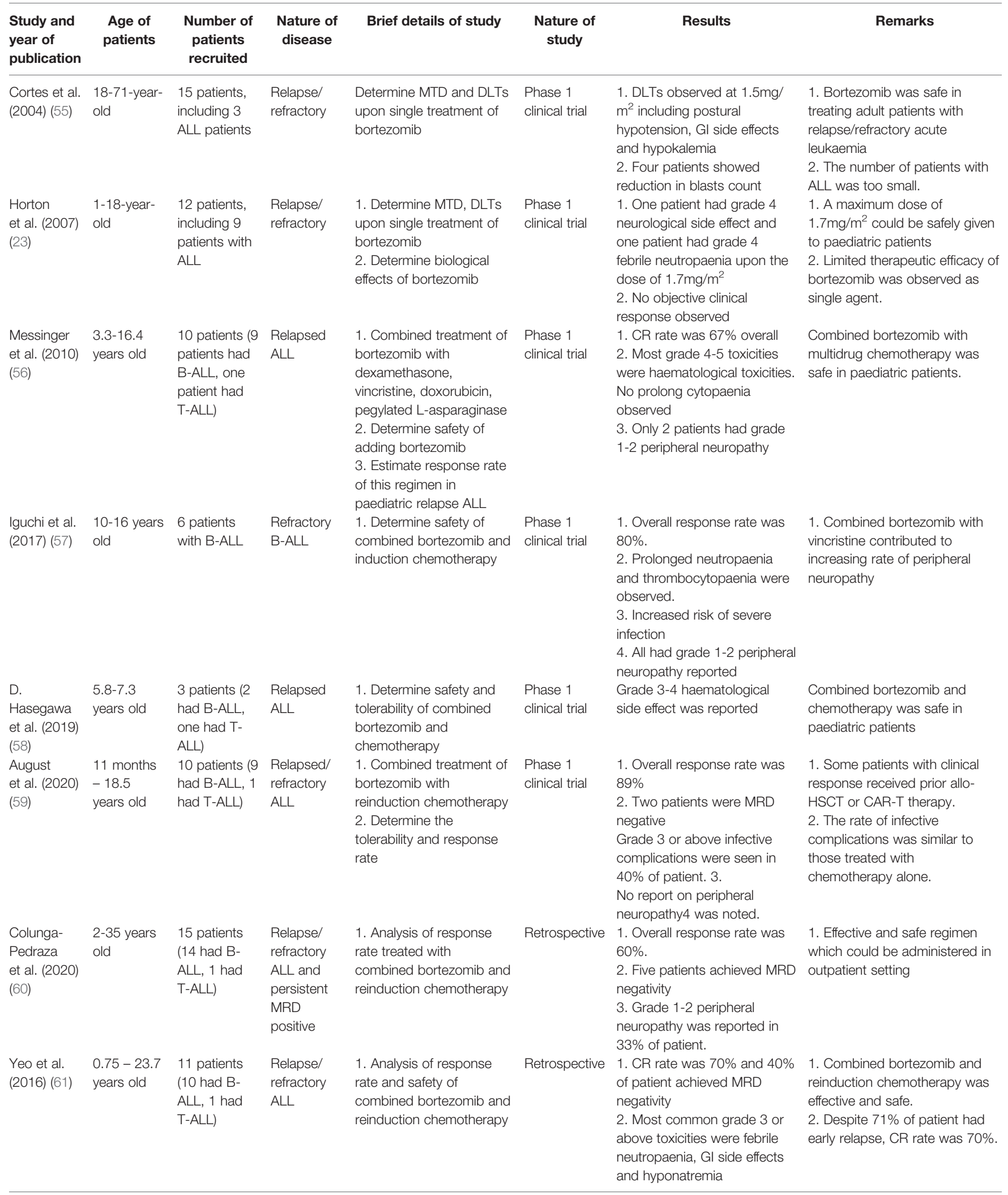


TABLE 1 | Continued

\begin{tabular}{|c|c|c|c|c|c|}
\hline $\begin{array}{l}\text { Study and } \\
\text { year of } \\
\text { publication }\end{array}$ & $\begin{array}{c}\text { Age of } \\
\text { patients }\end{array}$ & $\begin{array}{c}\text { Number of } \\
\text { patients } \\
\text { recruited }\end{array}$ & $\begin{array}{c}\text { Nature of } \\
\text { disease }\end{array}$ & Brief details of study & $\begin{array}{l}\text { Nature of } \\
\text { study }\end{array}$ \\
\hline $\begin{array}{l}\text { Messinger } \\
\text { et al. (2012) } \\
(62)\end{array}$ & $\begin{array}{l}1.3-22.3 \\
\text { years old }\end{array}$ & $\begin{array}{l}22 \text { patients } \\
\text { ( } 20 \text { had B- } \\
\text { ALL and } 2 \\
\text { had T-ALL) }\end{array}$ & $\begin{array}{l}\text { Relapse } \\
\text { ALL }\end{array}$ & $\begin{array}{l}\text { 1. Combined treatment of } \\
\text { bortezomib with } \\
\text { dexamethasone, } \\
\text { vincristine, doxorubicin, } \\
\text { pegylated L-asparaginase } \\
\text { 2. Determine response } \\
\text { rate and safety profile }\end{array}$ & Phase 2 trial \\
\hline $\begin{array}{l}\text { A. Bertaina } \\
\text { et al. (2017) } \\
\text { (63) }\end{array}$ & $\begin{array}{l}2.6-21 \\
\text { years old }\end{array}$ & $\begin{array}{l}37 \text { patients } \\
\text { ( } 30 \text { had } B- \\
\text { ALL and } 7 \\
\text { had T-ALL) }\end{array}$ & $\begin{array}{l}\text { Relapse/ } \\
\text { refractory } \\
\text { ALL }\end{array}$ & $\begin{array}{l}\text { 1. Combined treatment of } \\
\text { bortezomib with } \\
\text { dexamethasone, } \\
\text { doxorubicin, vincristine } \\
\text { and pegylated } \\
\text { asparaginase. } \\
\text { 2. Assess response rate } \\
\text { and safety }\end{array}$ & Prospective \\
\hline $\begin{array}{l}\text { Horton } \\
\text { et al. (2019) } \\
(64)\end{array}$ & $\begin{array}{l}\text { 1-31 years } \\
\text { old }\end{array}$ & $\begin{array}{l}135 \text { patients } \\
\text { (103 had B- } \\
\text { ALL, } 22 \text { had } \\
\text { T-ALL) }\end{array}$ & $\begin{array}{l}\text { Relapse } \\
\text { ALL }\end{array}$ & $\begin{array}{l}\text { 1. Combined bortezomib } \\
\text { and reinduction } \\
\text { chemotherapy } \\
\text { 2. Evaluate the CR2 rate } \\
\text { of the regimen }\end{array}$ & Phase 2 trial \\
\hline
\end{tabular}

Roy et al. 1-18 years 25 patients (2019) (65) old (All patients were B-ALL)

First relapse 1. Combined treatment of Phase 2 trial of ALL bortezomib and cytarabine-based reduced intensity protocol 2. Assess response rate, EFS and OS

Kaspers 1-18 years et al. (2018) old (66)

1. Assess efficacy of combined bortezomib and less intensive reinduction
29 patients (25 had BALL, 4 had T-ALL)
Relapse/ refractory

ALL

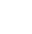

Nachmias Adults (>18 9 patients (5 Relapsed/ et al. (2018) years old) (67) had B-ALL, 4 refractory had T-ALL) ALL chemotherapy

2. Patients were randomized into earlybortezomib group and late-bortezomib group

1. Combined treatment of Prospective bortezomib with hyperCVAD or high-dose methotrexate and cytarabine 2. Assess response and safety

$\begin{array}{ll}\text { Jain et al. } & \text { Age }>14 \\ (2021)(68) & \text { years old }\end{array}$

34 patients 34 patients
Open-label, randomized control phase 2 trial

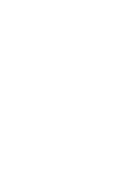

Phase 2 clinical trial

Newly
diagnosed
Ph-ve

1. Treated with combination of bortezomib, rituximab and
1. CR2 rate was $88 \%$ 2. Post-induction MRD negative rate was $69 \%$ 3. Median period of blood count recovery was 41 days with no reports on prolonged hospital stay due to sepsis 4. One-year EFS and OS was $75 \%$ and $80 \%$ respectively

1. No statistically significant difference in efficacy between early and late-bortezomib group was observed.

2. Overall response rate was $60 \%$

3. Nine patients had febrile neutropaenia

4. Two patients had grade 34 peripheral neuropathy

1. Overall response rate was $78 \%$ (All patient with B-ALL and 2 patients with T-ALL showed response) 2. Only 2 patients had grade 1-2 peripheral neuropathy 3. Five patients had febrile neutropaenia but none of them had grade 3-4 sepsis 1. Post-induction MRD negative rate was $71 \%$ (versus 52\% in historical
1. B-ALL showed better response rate $(80 \%$ in B-ALL vs none showed response in $\mathrm{T}$ -

ALL)

2. High rate of infective complications was noted and administration of prophylatic antimicrobials could prevent fatal infective complications

1. T-ALL also achieved good outcome (CR rate $71.4 \%$ ). 2. Background of high risk for invasive fungal infection was noted in those patients and it contributed to the death in the trial.

3. Antimicrobial prophylaxis was needed

1. Combined bortezomib and reinduction chemotherapy was effective

2. Low rate of grade 3 or above peripheral neuropathy was observed.

3. No significant increase in fata infective complications was noted when compared with previous cohorts 1. Combined bortezomib and reduced intensity regimen was effective in achieving $\mathrm{CR} 2$ and MRD negativity in B-ALL 2. Safe regimen in paediatric patients

1. Combined bortezomib with less intensive reinduction chemotherapeutic regimen was effective

2. Favorable side effect profiles with few serious adverse effects were seen.

1. Combined bortezomib with chemotherapy was effective and safe in adult population. 2. Two T-ALL patients obtained $\mathrm{CR}$ and they were treated with 2-3 lines of therapy.

1. Combined bortezomib, rituximab and paediatric protocol was highly effective with 
TABLE 1 | Continued

\begin{tabular}{|c|c|c|c|c|c|c|c|}
\hline $\begin{array}{l}\text { Study and } \\
\text { year of } \\
\text { publication }\end{array}$ & $\begin{array}{l}\text { Age of } \\
\text { patients }\end{array}$ & $\begin{array}{c}\text { Number of } \\
\text { patients } \\
\text { recruited }\end{array}$ & $\begin{array}{l}\text { Nature of } \\
\text { disease }\end{array}$ & Brief details of study & $\begin{array}{l}\text { Nature of } \\
\text { study }\end{array}$ & Results & Remarks \\
\hline & & & $\begin{array}{l}\text { CD20- } \\
\text { positive B- } \\
\text { ALL }\end{array}$ & $\begin{array}{l}\text { paediatric-inspired } \\
\text { protocol }\end{array}$ & & $\begin{array}{l}\text { cohort) } \\
\text { 2. Grade } 3-4 \text { infective } \\
\text { complications was seen in } 23 \\
\text { patients } \\
\text { 3. One induction death versus } \\
7.9 \% \text { induction death in } \\
\text { historical cohort } \\
\text { 4. Grade } 1-2 \text { peripheral } \\
\text { neuropathy was noted in } 26 \% \\
\text { of patient } \\
\text { 5. EFS and OS at } 21 \text {-month } \\
\text { was } 79 \% \text {. }\end{array}$ & $\begin{array}{l}\text { high MRD negativity rate } \\
\text { 2. Low rate of severe toxicities } \\
\text { 3. Difficult to attribute the } \\
\text { beneficial effect on rituximab or } \\
\text { bortezomib }\end{array}$ \\
\hline $\begin{array}{l}\text { Wartman t } \\
\text { al. (2016) } \\
(69)\end{array}$ & $\begin{array}{l}\text { Adult aged } \\
>18 \text { years } \\
\text { old (median } \\
\text { age } 70 \\
\text { years old) }\end{array}$ & $\begin{array}{l}18 \text { patients } \\
\text { (17 had AML } \\
\text { and } 1 \text { had } \\
\text { ALL) }\end{array}$ & $\begin{array}{l}\text { Relapse/ } \\
\text { refractory } \\
\text { AML or ALL }\end{array}$ & $\begin{array}{l}\text { 1. To determine the MTD } \\
\text { and DLTs of carfilzomib }\end{array}$ & $\begin{array}{l}\text { Phase } 1 \\
\text { clinical trial }\end{array}$ & $\begin{array}{l}\text { 1. No DLTS observed upon } \\
\text { treatment with } 56 \mathrm{mg} / \mathrm{m}^{2} \\
\text { 2. CHF exacerbation occurred } \\
\text { in } 11 \% \text { of patient and they } \\
\text { had pre-existing heart disease } \\
\text { 3. Only modest response was } \\
\text { observed ( } 2 \text { patients had } \\
\text { partial response only) }\end{array}$ & $\begin{array}{l}\text { 1. Carfilzomib was safe and } \\
\text { tolerable in adult population } \\
\text { 2. Limited efficacy was observed } \\
\text { upon single treatment of } \\
\text { carfilzomib }\end{array}$ \\
\hline $\begin{array}{l}\text { Jonas et al. } \\
(2021)(70)\end{array}$ & $\begin{array}{l}\text { Adult aged } \\
\text { 18-64 years } \\
\text { old }\end{array}$ & $\begin{array}{l}10 \text { patients (8 } \\
\text { had B-ALL, } 2 \\
\text { had T-ALL) }\end{array}$ & $\begin{array}{l}\text { Newly } \\
\text { diagnosed, } \\
\text { deno Ph-ve } \\
\text { ALL }\end{array}$ & $\begin{array}{l}\text { 1. Combined treatment of } \\
\text { carfilzomib and hyper- } \\
\text { CVAD } \\
\text { 2. Determine safety and } \\
\text { response rate }\end{array}$ & $\begin{array}{l}\text { Phase } 1 \\
\text { clinical trial }\end{array}$ & $\begin{array}{l}\text { 1. No patient had DLTs } \\
\text { 2. Most grade } 3-4 \text { toxicities } \\
\text { were haematological toxicities } \\
\text { 3. Febrile neutropaenia } \\
\text { occurred in } 60 \% \text { of patient } \\
\text { 4. No grade } 5 \text { events and no } \\
\text { cardiac events were noted } \\
\text { 5. CR rate was } 100 \% \text { and } \\
80 \% \text { of patient were MRD } \\
\text { negative after } 4 \text { cycles }\end{array}$ & $\begin{array}{l}\text { 1. High MRD negativity rate was } \\
\text { noted when treated with this } \\
\text { regimen } \\
\text { 2. The regimen was safe and } \\
\text { tolerable in adult }\end{array}$ \\
\hline
\end{tabular}

ALL, Acute lymphoblastic leukaemia; MTD, Maximum tolerated dose; DLTS, Dose-limiting toxicities; Gl, Gastrointestinal; MRD, Minimal residual disease; B-ALL, B lymphoblastic leukaemia; CR, Complete remission; T-ALL, Tlymphoblastic leukaemia; Allo-HSCT, Allogenic haemopoietic stem cell transplant; CAR-T, Chimeric antigen receptor T-cell; OS, Overall survival; EFS, Event-free survival; Ph-ve, Philadelphia chromosome negative; AML, Acute myeloid leukaemia; CHF, Congestive heart failure.

developed peripheral neuropathy (62). Recent clinical studies also demonstrated excellent therapeutic efficacy and safety profile for bortezomib-based treatment. A. Bertaina et al. recruited 37 patients with relapse/refractory ALL aged 2-21year-old. The overall response rate was $73 \%$ and $38 \%$ of them were MRD negative. Three patients died from infective complications and 5 patients had peripheral neuropathy (63). Horton et al. recruited 135 pediatrics and young adult patients (1-31 years old) with relapse/refractory ALL. They were treated with combined bortezomib and reinduction chemotherapy. The CR rate was $68 \%$ and $64 \%$ of patients were MRD negative after 3 cycles of treatment. The outcome of relapse/refractory T-ALL was excellent with CR rate of $68 \%$ (64). Combined bortezomib with reinduction chemotherapy also demonstrated improved event-free survival (EFS) and overall survival (OS) compared with supportive treatment in pediatric relapse/refractory ALL (65). Kaspers et al. showed $60 \%$ overall response rate in pediatric patients with relapse/refractory disease (66). Nachmias et al. showed $78 \%$ overall response rate in adult patients with relapse/ refractory ALL with minimal toxicities when treated with combined chemotherapy and bortezomib (67). Jain et al. showed that combined pediatric-inspired regimen with rituximab and bortezomib was highly effective in treating newly diagnosed CD20-positive B-ALL in adolescent and adult patients. They showed that $71 \%$ of them was MRD negative after induction versus $52 \%$ when treated with chemotherapy alone (68).

Carfilzomib also showed to be active against B-ALL and TALL in pre-clinical studies $(30,47,48,71,72)$. Pre-clinical study showed that ixazomib was active against ALL despite it was less potent than bortezomib (73). A phase 1 trial of carfilzomib conducted on adult patients showed acceptable side effects with only $11 \%$ of them had congestive heart failure and all of them had pre-existing heart disease (69). A recent phase 1 study recruited 10 adult patients with newly diagnosed ALL and they were treated with combined hyper-CVAD and carfilzomib. They achieved $80 \%$ of MRD negativity rate, compared with $53 \%$ when treated with hyper-CVAD alone. None of them had cardiac events (70).

The efficacy and safely of combined bortezomib and chemotherapy in treating relapse/refractory ALL had been proven in pediatric population. However, more studies are needed to evaluate this strategy in treating relapse/refractory disease in adult. The findings of high MRD negativity rate when combining proteasome inhibitors with chemotherapy in treating newly diagnosed ALL in adult is a promising finding, since MRD 
is crucial determinant of prognosis in adult ALL (74-76). This therapeutic strategy for newly diagnosed ALL can potentially improve outcome of ALL, particularly in adult patients.

\section{CONCLUDING LANDMARK AND FUTURE DIRECTION}

In conclusion, the safety and efficacy of bortezomib in treating paediatric relapse/refractory ALL had been demonstrated in clinical studies. Data from clinical studies of carfilzomib and ixazomib are emerging. Various mechanisms of action of proteasome inhibitors were implicated in ALL. The expression of immunoproteasome is increased in ALL and thus selective inhibition of immunoproteasome is a promising approach in achieving maximal therapeutic efficacy and minimizing undesirable side effects.

However, large-scale clinical trials of proteasome inhibitors in treating relapse/refractory adult ALL are lacking. Moreover, the use of proteasome inhibitors-based regimen in treating newly diagnosed ALL is under-investigated. Further clinical studies are needed to establish the role of proteasome inhibitors in treating

\section{REFERENCES}

1. Pui CH, Evans WE. Treatment of Acute Lymphoblastic Leukemia. $N$ Engl $J$ Med (2006) 354(2):166-78. doi: 10.1056/NEJMra052603

2. Rafei H, Kantarjian HM, Jabbour EJ. Recent Advances in the Treatment of Acute Lymphoblastic Leukemia. Leuk Lymphoma (2019) 60(11):2606-21. doi: 10.1080/10428194.2019.1605071

3. Raedler L. Velcade (Bortezomib) Receives 2 New FDA Indications For Retreatment of Patients With Multiple Myeloma and for First-Line Treatment of Patients With Mantle-Cell Lymphoma. Am Health Drug Benefits (2015) 8:135-40.

4. Yin D, Zhou H, Kumagai T, Liu G, Ong JM, Black KL, et al. Proteasome Inhibitor PS-341 Causes Cell Growth Arrest and Apoptosis in Human Glioblastoma Multiforme (GBM). Oncogene (2005) 24(3):344-54. doi: 10.1038/sj.onc.1208225

5. Hong YS, Hong SW, Kim SM, Jin DH, Shin JS, Yoon DH, et al. Bortezomib Induces G2-M Arrest in Human Colon Cancer Cells Through ROS-Inducible Phosphorylation of ATM-Chk1. Int J Oncol (2012) 41(1):76-82. doi: 10.3892/ ijo. 2012.1448

6. Fogli S, Galimberti S, Gori V, Del Re M, Danesi R. Pharmacology Differences Among Proteasome Inhibitors: Implications for Their Use in Clinical Practice. Pharmacol Res (2021) 167:105537. doi: 10.1016/j.phrs.2021.105537

7. Tan CRC, Abdul-Majeed S, Cael B, Barta SK. Clinical Pharmacokinetics and Pharmacodynamics of Bortezomib. Clin Pharmacokinet (2019) 58(2):157-68. doi: 10.1007/s40262-018-0679-9

8. Besse A, Besse L, Kraus M, Mendez-Lopez M, Bader J, Xin BT, et al. Proteasome Inhibition in Multiple Myeloma: Head-To-Head Comparison of Currently Available Proteasome Inhibitors. Cell Chem Biol (2019) 26 (3):340-51 e3. doi: 10.1016/j.chembiol.2018.11.007

9. Waxman AJ, Clasen S, Hwang WT, Garfall A, Vogl DT, Carver J, et al. Carfilzomib-Associated Cardiovascular Adverse Events: A Systematic Review and Meta-Analysis. JAMA Oncol (2018) 4(3):e174519. doi: 10.1001/ jamaoncol.2017.4519

10. Efentakis P, Kremastiotis G, Varela A, Nikolaou PE, Papanagnou ED, Davos $\mathrm{CH}$, et al. Molecular Mechanisms of Carfilzomib-Induced Cardiotoxicity in Mice and the Emerging Cardioprotective Role of Metformin. Blood (2019) 133 (7):710-23. doi: 10.1182/blood-2018-06-858415

11. Kupperman E, Lee EC, Cao Y, Bannerman B, Fitzgerald M, Berger A, et al. Evaluation of the Proteasome Inhibitor MLN9708 in Preclinical Models of newly diagnosed ALL and relapse/refractory ALL in adult. Moreover, clinical trials of newer generation of proteasome inhibitors are also needed.

Despites its therapeutic efficacy, the mechanism of action of proteasome inhibitors are not well understood in certain subtypes of ALL, particularly NOTCH1 wild-type T-ALL including ETPALL and Ph-like ALL which confer a poor prognosis $(35,77,78)$. Further studies are needed to elucidate the underlying mechanism of action of proteasome inhibitors in those subtypes of ALL. Optimal combination therapeutic strategy can be developed after throughout understanding the mechanism of action. It can enhance the therapeutic efficacy of proteasome inhibitors and thus improve the prognosis of patients with ALL. Lastly, the mechanism of action of newer proteasome inhibitors is underinvestigated and more mechanistic studies are needed.

\section{AUTHOR CONTRIBUTIONS}

CS planned and conceptualized the article. Both CS and MM wrote the article. The article had been reviewed by both CS and MM before submission.
Human Cancer. Cancer Res (2010) 70(5):1970-80. doi: 10.1158/00085472.CAN-09-2766

12. Li J, Bao L, Xia Z, Wang S, Zhou X, Ding K, et al. Ixazomib-Based Frontline Therapy in Patients With Newly Diagnosed Multiple Myeloma in Real-Life Practice Showed Comparable Efficacy and Safety Profile With Those Reported in Clinical Trial: A Multi-Center Study. Ann Hematol (2020) 99(11):2589-98. doi: 10.1007/s00277-020-04234-9

13. Richardson PG, Sonneveld P, Schuster MW, Irwin D, Stadtmauer EA, Facon T, et al. Safety and Efficacy of Bortezomib in High-Risk and Elderly Patients With Relapsed Multiple Myeloma. Br J Haematol (2007) 137(5):429-35. doi: 10.1111/j.1365-2141.2007.06585.x

14. Berkers CR, Leestemaker Y, Schuurman KG, Ruggeri B, Jones-Bolin S, Williams M, et al. Probing the Specificity and Activity Profiles of the Proteasome Inhibitors Bortezomib and Delanzomib. Mol Pharm (2012) 9 (5):1126-35. doi: 10.1021/mp2004143

15. Hasinoff BB. Progress Curve Analysis of the Kinetics of Slow-Binding Anticancer Drug Inhibitors of the 20S Proteasome. Arch Biochem Biophys (2018) 639:52-8. doi: 10.1016/j.abb.2017.12.020

16. Vogl DT, Martin TG, Vij R, Hari P, Mikhael JR, Siegel D, et al. Phase I/II Study of the Novel Proteasome Inhibitor Delanzomib (CEP-18770) for Relapsed and Refractory Multiple Myeloma. Leuk Lymphoma (2017) 58(8):1872-9. doi: 10.1080/10428194.2016.1263842

17. Ghobrial IM, Vij R, Siegel D, Badros A, Kaufman J, Raje N, et al. A Phase Ib/II Study of Oprozomib in Patients With Advanced Multiple Myeloma and Waldenstrom Macroglobulinemia. Clin Cancer Res (2019) 25(16):4907-16. doi: 10.1158/1078-0432.CCR-18-3728

18. Hari P, Paba-Prada CE, Voorhees PM, Frye J, Chang YL, Moreau P, et al. Efficacy and Safety Results From a Phase 1b/2, Multicenter, Open-Label Study of Oprozomib and Dexamethasone in Patients With Relapsed and/or Refractory Multiple Myeloma. Leuk Res (2019) 83:106172. doi: 10.1016/ j.leukres.2019.106172

19. Levin N, Spencer A, Harrison SJ, Chauhan D, Burrows FJ, Anderson KC, et al. Marizomib Irreversibly Inhibits Proteasome to Overcome Compensatory Hyperactivation in Multiple Myeloma and Solid Tumour Patients. $\mathrm{Br} J$ Haematol (2016) 174(5):711-20. doi: 10.1111/bjh.14113

20. Spencer A, Harrison S, Zonder J, Badros A, Laubach J, Bergin K, et al. A Phase 1 Clinical Trial Evaluating Marizomib, Pomalidomide and Low-Dose Dexamethasone in Relapsed and Refractory Multiple Myeloma (NPI-0052-107): 
Final Study Results. Br J Haematol (2018) 180(1):41-51. doi: 10.1111/ bjh. 14987

21. Richardson PG, Zimmerman TM, Hofmeister CC, Talpaz M, Chanan-Khan AA, Kaufman JL, et al. Phase 1 Study of Marizomib in Relapsed or Relapsed and Refractory Multiple Myeloma: NPI-0052-101 Part 1. Blood (2016) 127 (22):2693-700. doi: 10.1182/blood-2015-12-686378

22. Hideshima T, Chauhan D, Richardson P, Mitsiades C, Mitsiades N, Hayashi T, et al. NF-Kappa B as a Therapeutic Target in Multiple Myeloma. J Biol Chem (2002) 277(19):16639-47. doi: 10.1074/jbc.M200360200

23. Horton TM, Pati D, Plon SE, Thompson PA, Bomgaars LR, Adamson PC, et al. A Phase 1 Study of the Proteasome Inhibitor Bortezomib in Pediatric Patients With Refractory Leukemia: A Children's Oncology Group Study. Clin Cancer Res (2007) 13(5):1516-22. doi: 10.1158/1078-0432.CCR-06-2173

24. Hu X, Xu J, Sun A, Shen Y, He G, Guo F. Successful T-Cell Acute Lymphoblastic Leukemia Treatment With Proteasome Inhibitor Bortezomib Based on Evaluation of Nuclear Factor-kappaB Activity. Leuk Lymphoma (2011) 52(12):2393-5. doi: 10.3109/10428194.2011.593271

25. Belver L, Ferrando A. The Genetics and Mechanisms of T Cell Acute Lymphoblastic Leukaemia. Nat Rev Cancer (2016) 16(8):494-507. doi: $10.1038 /$ nrc. 2016.63

26. Vilimas T, Mascarenhas J, Palomero T, Mandal M, Buonamici S, Meng F, et al. Targeting the NF-kappaB Signaling Pathway in Notch1-Induced T-Cell Leukemia. Nat Med (2007) 13(1):70-7. doi: 10.1038/nm1524

27. Koyama D, Kikuchi J, Hiraoka N, Wada T, Kurosawa H, Chiba S, et al. Proteasome Inhibitors Exert Cytotoxicity and Increase Chemosensitivity via Transcriptional Repression of Notch1 in T-Cell Acute Lymphoblastic Leukemia. Leukemia (2014) 28(6):1216-26. doi: 10.1038/leu.2013.366

28. Szczepanek J, Konatkowska B, Juraszewska E, Badowska W, Olejnik I, Kuzmicz M, et al. Differential Ex Vivo Activity of Bortezomib in Newly Diagnosed Paediatric Acute Lymphoblastic and Myeloblastic Leukaemia. Anticancer Res (2010) 30(6):2119-21.

29. Murata S, Takahama Y, Kasahara M, Tanaka K. The Immunoproteasome and Thymoproteasome: Functions, Evolution and Human Disease. Nat Immunol (2018) 19(9):923-31. doi: 10.1038/s41590-018-0186-z

30. Niewerth D, Franke NE, Jansen G, Assaraf YG, van Meerloo J, Kirk CJ, et al. Higher Ratio Immune Versus Constitutive Proteasome Level as Novel Indicator of Sensitivity of Pediatric Acute Leukemia Cells to Proteasome Inhibitors. Haematologica (2013) 98(12):1896-904. doi: 10.3324/haematol. 2013.092411

31. Jenkins TW, Downey-Kopyscinski SL, Fields JL, Rahme GJ, Colley WC, Israel MA, et al. Activity of Immunoproteasome Inhibitor ONX-0914 in Acute Lymphoblastic Leukemia Expressing MLL-AF4 Fusion Protein. Sci Rep (2021) 11(1):10883. doi: 10.1038/s41598-021-90451-9

32. Jagani Z, Singh A, Khosravi-Far R. FoxO Tumor Suppressors and BCR-ABLInduced Leukemia: A Matter of Evasion of Apoptosis. Biochim Biophys Acta (2008) 1785(1):63-84. doi: 10.1016/j.bbcan.2007.10.003

33. Jagani Z, Song K, Kutok JL, Dewar MR, Melet A, Santos T, et al. Proteasome Inhibition Causes Regression of Leukemia and Abrogates BCR-ABL-Induced Evasion of Apoptosis in Part Through Regulation of Forkhead Tumor Suppressors. Cancer Res (2009) 69(16):6546-55. doi: 10.1158/00085472.CAN-09-0605

34. Dewar R, Chen ST, Yeckes-Rodin H, Miller K, Khosravi-Far R. Bortezomib Treatment Causes Remission in a Ph+ALL Patient and Reveals FoxO as a Theranostic Marker. Cancer Biol Ther (2011) 11(6):552-8. doi: 10.4161/ cbt.11.6.14675

35. Tasian SK, Loh ML, Hunger SP. Philadelphia Chromosome-Like Acute Lymphoblastic Leukemia. Blood (2017) 130(19):2064-72. doi: 10.1182/ blood-2017-06-743252

36. Shiraz P, Payne KJ, Muffly L. The Current Genomic and Molecular Landscape of Philadelphia-Like Acute Lymphoblastic Leukemia. Int J Mol Sci (2020) 21 (6):1-17. doi: 10.3390/ijms21062193

37. Tasian SK, Doral MY, Borowitz MJ, Wood BL, Chen IM, Harvey RC, et al. Aberrant STAT5 and PI3K/mTOR Pathway Signaling Occurs in Human CRLF2-Rearranged B-Precursor Acute Lymphoblastic Leukemia. Blood (2012) 120(4):833-42. doi: 10.1182/blood-2011-12-389932

38. Verma G, Datta M. The Critical Role of JNK in the ER-Mitochondrial Crosstalk During Apoptotic Cell Death. J Cell Physiol (2012) 227(5):1791-5. doi: $10.1002 /$ jcp. 22903
39. Hideshima T, Mitsiades C, Akiyama M, Hayashi T, Chauhan D, Richardson P, et al. Molecular Mechanisms Mediating Antimyeloma Activity of Proteasome Inhibitor PS-341. Blood (2003) 101(4):1530-4. doi: 10.1182/blood-2002-082543

40. Saunders P, Cisterne A, Weiss J, Bradstock KF, Bendall LJ. The Mammalian Target of Rapamycin Inhibitor RAD001 (Everolimus) Synergizes With Chemotherapeutic Agents, Ionizing Radiation and Proteasome Inhibitors in Pre-B Acute Lymphocytic Leukemia. Haematologica (2011) 96(1):69-77. doi: 10.3324/haematol.2010.026997

41. Schroder M, Kaufman RJ. The Mammalian Unfolded Protein Response. Annu Rev Biochem (2005) 74:739-89. doi: 10.1146/annurev.biochem.73.011303.074134

42. Kostova Z, Wolf DH. For Whom the Bell Tolls: Protein Quality Control of the Endoplasmic Reticulum and the Ubiquitin-Proteasome Connection. EMBO J (2003) 22(10):2309-17. doi: 10.1093/emboj/cdg227

43. Obeng EA, Carlson LM, Gutman DM, Harrington WJJr., Lee KP, Boise LH. Proteasome Inhibitors Induce a Terminal Unfolded Protein Response in Multiple Myeloma Cells. Blood (2006) 107(12):4907-16. doi: 10.1182/blood2005-08-3531

44. Hetz C, Zhang K, Kaufman RJ. Mechanisms, Regulation and Functions of the Unfolded Protein Response. Nat Rev Mol Cell Biol (2020) 21(8):421-38. doi: 10.1038/s41580-020-0250-z

45. Buontempo F, Orsini E, Lonetti A, Cappellini A, Chiarini F, Evangelisti C, et al. Synergistic Cytotoxic Effects of Bortezomib and CK2 Inhibitor CX-4945 in Acute Lymphoblastic Leukemia: Turning Off the Prosurvival ER Chaperone BIP/Grp78 and Turning on the Pro-Apoptotic NF-Kappab. Oncotarget (2016) 7(2):1323-40. doi: 10.18632/oncotarget.6361

46. Sontag EM, Samant RS, Frydman J. Mechanisms and Functions of Spatial Protein Quality Control. Annu Rev Biochem (2017) 86:97-122. doi: 10.1146/ annurev-biochem-060815-014616

47. Liu H, Westergard TD, Cashen A, Piwnica-Worms DR, Kunkle L, Vij R, et al. Proteasome Inhibitors Evoke Latent Tumor Suppression Programs in Pro-B MLL Leukemias Through MLL-Af4. Cancer Cell (2014) 25(4):530-42. doi: 10.1016/j.ccr.2014.03.008

48. Cheung LC, de Kraa R, Oommen J, Chua GA, Singh S, Hughes AM, et al. Preclinical Evaluation of Carfilzomib for Infant KMT2A-Rearranged Acute Lymphoblastic Leukemia. Front Oncol (2021) 11:631594. doi: 10.3389/ fonc.2021.631594

49. Niewerth D, Jansen G, Assaraf YG, Zweegman S, Kaspers GJ, Cloos J. Molecular Basis of Resistance to Proteasome Inhibitors in Hematological Malignancies. Drug Resist Update (2015) 18:18-35. doi: 10.1016/j.drup. 2014.12.001

50. Franke NE, Niewerth D, Assaraf YG, van Meerloo J, Vojtekova K, van Zantwijk $\mathrm{CH}$, et al. Impaired Bortezomib Binding to Mutant Beta5 Subunit of the Proteasome is the Underlying Basis for Bortezomib Resistance in Leukemia Cells. Leukemia (2012) 26(4):757-68. doi: 10.1038/leu.2011.256

51. Lu S, Yang J, Song X, Gong S, Zhou H, Guo L, et al. Point Mutation of the Proteasome Beta5 Subunit Gene is an Important Mechanism of Bortezomib Resistance in Bortezomib-Selected Variants of Jurkat T Cell Lymphoblastic Lymphoma/Leukemia Line. J Pharmacol Exp Ther (2008) 326(2):423-31. doi: 10.1124/jpet.108.138131

52. Lu S, Yang J, Chen Z, Gong S, Zhou H, Xu X, et al. Different Mutants of PSMB5 Confer Varying Bortezomib Resistance in $\mathrm{T}$ Lymphoblastic Lymphoma/Leukemia Cells Derived From the Jurkat Cell Line. Exp Hematol (2009) 37(7):831-7. doi: 10.1016/j.exphem.2009.04.001

53. Lu S, Chen Z, Yang J, Chen L, Gong S, Zhou H, et al. Overexpression of the PSMB5 Gene Contributes to Bortezomib Resistance in T-Lymphoblastic Lymphoma/Leukemia Cells Derived From Jurkat Line. Exp Hematol (2008) 36(10):1278-84. doi: 10.1016/j.exphem.2008.04.013

54. Niewerth D, Kaspers GJ, Assaraf YG, van Meerloo J, Kirk CJ, Anderl J, et al. Interferon-Gamma-Induced Upregulation of Immunoproteasome Subunit Assembly Overcomes Bortezomib Resistance in Human Hematological Cell Lines. J Hematol Oncol (2014) 7:7. doi: 10.1186/1756-8722-7-7

55. Cortes J, Thomas D, Koller C, Giles F, Estey E, Faderl S, et al. Phase I Study of Bortezomib in Refractory or Relapsed Acute Leukemias. Clin Cancer Res (2004) 10(10):3371-6. doi: 10.1158/1078-0432.CCR-03-0508

56. Messinger Y, Gaynon P, Raetz E, Hutchinson R, Dubois S, Glade-Bender J, et al. Phase I Study of Bortezomib Combined With Chemotherapy in Children With Relapsed Childhood Acute Lymphoblastic Leukemia (ALL): A Report 
From the Therapeutic Advances in Childhood Leukemia (TACL) Consortium. Pediatr Blood Cancer (2010) 55(2):254-9. doi: 10.1002/ pbc. 22456

57. Iguchi A, Cho Y, Sugiyama M, Terashita Y, Ariga T, Hosoya $\mathrm{Y}$, et al. Bortezomib Combined With Standard Induction Chemotherapy in Japanese Children With Refractory Acute Lymphoblastic Leukemia. Int J Hematol (2017) 106(2):291-8. doi: 10.1007/s12185-017-2235-Z

58. Hasegawa D, Yoshimoto Y, Kimura S, Kumamoto T, Maeda N, Hara J, et al. Bortezomib-Containing Therapy in Japanese Children With Relapsed Acute Lymphoblastic Leukemia. Int J Hematol (2019) 110(5):627-34. doi: 10.1007/ s12185-019-02714-x

59. August KJ, Guest EM, Lewing K, Hays JA, Gamis AS. Treatment of Children With Relapsed and Refractory Acute Lymphoblastic Leukemia With Mitoxantrone, Vincristine, Pegaspargase, Dexamethasone, and Bortezomib. Pediatr Blood Cancer (2020) 67(3):e28062. doi: 10.1002/pbc.28062

60. Colunga-Pedraza JE, Gonzalez-Llano O, Gonzalez-Martinez CE, GomezAlmaguer D, Yanez-Reyes JM, Jimenez-Antolinez V, et al. Outpatient Low Toxic Regimen With Bortezomib in Relapsed/Refractory Acute Lymphoblastic Leukemia in Pediatrics and AYA Patients: Single-Center Mexican Experience. Pediatr Blood Cancer (2020) 67(5):e28241. doi: 10.1002/pbc.28241

61. Yeo KK, Gaynon PS, Fu CH, Wayne AS, Sun W. Bortezomib, Dexamethasone, Mitoxantrone, and Vinorelbine (BDMV): An Active Reinduction Regimen for Children With Relapsed Acute Lymphoblastic Leukemia and Asparaginase Intolerance. J Pediatr Hematol Oncol (2016) 38(5):345-9. doi: 10.1097/ MPH.0000000000000560

62. Messinger YH, Gaynon PS, Sposto R, van der Giessen J, Eckroth E, Malvar J, et al. Bortezomib With Chemotherapy Is Highly Active in Advanced BPrecursor Acute Lymphoblastic Leukemia: Therapeutic Advances in Childhood Leukemia \& Lymphoma (TACL) Study. Blood (2012) 120 (2):285-90. doi: 10.1182/blood-2012-04-418640

63. Bertaina A, Vinti L, Strocchio L, Gaspari S, Caruso R, Algeri M, et al. The Combination of Bortezomib With Chemotherapy to Treat Relapsed/ Refractory Acute Lymphoblastic Leukaemia of Childhood. Br J Haematol (2017) 176(4):629-36. doi: 10.1111/bjh.14505

64. Horton TM, Whitlock JA, Lu X, O’Brien MM, Borowitz MJ, Devidas M, et al. Bortezomib Reinduction Chemotherapy in High-Risk ALL in First Relapse: A Report From the Children's Oncology Group. Br J Haematol (2019) 186 (2):274-85. doi: 10.1111/bjh.15919

65. Roy P, Islam R, Saha D, Gogoi M, Kumar Mishra D, Arora N, et al. Efficacy and Safety of a Bortezomib and Reduced-Intensity Cytarabine-Based Protocol, TMC ALLR1, for Relapsed Childhood ALL in India. $\mathrm{Br} J$ Haematol (2019) 186(6):861-5. doi: 10.1111/bjh.16005

66. Kaspers GJL, Niewerth D, Wilhelm BAJ, Scholte-van Houtem P, LopezYurda M, Berkhof J, et al. An Effective Modestly Intensive Re-Induction Regimen With Bortezomib in Relapsed or Refractory Paediatric Acute Lymphoblastic Leukaemia. Br J Haematol (2018) 181(4):523-7. doi: 10.1111/bjh.15233

67. Nachmias B, Shaulov A, Gatt ME, Shapira M, Gural A. A Bortezomib-Based Protocol Induces a High Rate of Complete Remission With Minor Toxicity in Adult Patients With Relapsed/Refractory Acute Lymphoblastic Leukemia. Acta Haematol (2018) 140(4):209-14. doi: 10.1159/000493252

68. Jain H, Sengar M, Goli VB, Thorat J, Tembhare P, Shetty D, et al. Bortezomib and Rituximab in De Novo Adolescent/Adult CD20-Positive, Ph-Negative Pre-B-Cell Acute Lymphoblastic Leukemia. Blood Adv (2021) 5(17):3436-44. doi: 10.1182/bloodadvances.2020003368
69. Wartman LD, Fiala MA, Fletcher T, Hawkins ER, Cashen A, DiPersio JF, et al A Phase I Study of Carfilzomib for Relapsed or Refractory Acute Myeloid and Acute Lymphoblastic Leukemia. Leuk Lymphoma (2016) 57(3):728-30. doi: 10.3109/10428194.2015.1076930

70. Jonas BA, Fisch SC, Rosenberg AS, Hoeg RT, Tuscano JM, Abedi M. Phase I Study of Escalating Doses of Carfilzomib With HyperCVAD in Patients With Newly Diagnosed Acute Lymphoblastic Leukemia. Am J Hematol (2021) 96 (4):E114-E7. doi: 10.1002/ajh.26105

71. Hosseini MS, Mohammadi MH, Vahabpour Roudsari R, Jafari L, Mashati P, Gharehbaghian A. Proteasome Inhibition by Carfilzomib Induced Apotosis and Autophagy in a T-Cell Acute Lymphoblastic Leukemia Cell Line. Iran J Pharm Res (2019) 18(Suppl1):132-45. doi: 10.22037/ijpr.2020.112692.13898

72. Takahashi K, Inukai T, Imamura T, Yano M, Tomoyasu C, Lucas DM, et al. Anti-Leukemic Activity of Bortezomib and Carfilzomib on B-Cell Precursor ALL Cell Lines. PloS One (2017) 12(12):e0188680. doi: 10.1371/journal. pone. 0188680

73. Roeten MSF, van Meerloo J, Kwidama ZJ, Ter Huizen G, Segerink WH, Zweegman S, et al. Pre-Clinical Evaluation of the Proteasome Inhibitor Ixazomib Against Bortezomib-Resistant Leukemia Cells and Primary Acute Leukemia Cells. Cells (2021) 10(3):1-14. doi: 10.3390/cells10030665

74. Chiaretti S, Foa R. Management of Adult Ph-Positive Acute Lymphoblastic Leukemia. Hematol Am Soc Hematol Educ Program (2015) 2015:406-13. doi: 10.1182/asheducation-2015.1.406

75. Nagafuji K, Miyamoto T, Eto T, Ogawa R, Okumura H, Takase K, et al. Prospective Evaluation of Minimal Residual Disease Monitoring to Predict Prognosis of Adult Patients With Ph-Negative Acute Lymphoblastic Leukemia. Eur J Haematol (2019) 103(3):164-71. doi: 10.1111/ejh.13268

76. Wang H, Zhou Y, Huang X, Zhang Y, Qian J, Li J, et al. Minimal Residual Disease Level Determined by Flow Cytometry Provides Reliable Risk Stratification in Adults With T-Cell Acute Lymphoblastic Leukaemia. $\mathrm{Br} \mathrm{J}$ Haematol (2021) 193(6):1096-104. doi: 10.1111/bjh.17424

77. Coustan-Smith E, Mullighan CG, Onciu M, Behm FG, Raimondi SC, Pei D, et al. Early T-Cell Precursor Leukaemia: A Subtype of Very High-Risk Acute Lymphoblastic Leukaemia. Lancet Oncol (2009) 10(2):147-56. doi: 10.1016/ S1470-2045(08)70314-0

78. Van Vlierberghe P, Ambesi-Impiombato A, De Keersmaecker K, Hadler M, Paietta E, Tallman MS, et al. Prognostic Relevance of Integrated Genetic Profiling in Adult T-Cell Acute Lymphoblastic Leukemia. Blood (2013) 122 (1):74-82. doi: 10.1182/blood-2013-03-491092

Conflict of Interest: The authors declare that the research was conducted in the absence of any commercial or financial relationships that could be construed as a potential conflict of interest.

Publisher's Note: All claims expressed in this article are solely those of the authors and do not necessarily represent those of their affiliated organizations, or those of the publisher, the editors and the reviewers. Any product that may be evaluated in this article, or claim that may be made by its manufacturer, is not guaranteed or endorsed by the publisher.

Copyright $\odot 2021$ Sin and Man. This is an open-access article distributed under the terms of the Creative Commons Attribution License (CC BY). The use, distribution or reproduction in other forums is permitted, provided the original author(s) and the copyright owner(s) are credited and that the original publication in this journal is cited, in accordance with accepted academic practice. No use, distribution or reproduction is permitted which does not comply with these terms. 